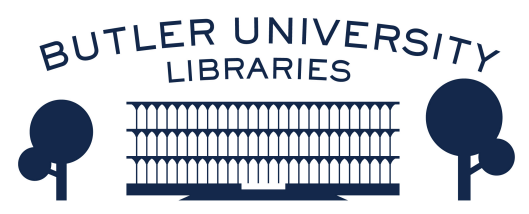

Journal of Hindu-Christian Studies

Volume 11

Article 16

January 1998

\title{
Book Review: "The Colors of Violence: Cultural Identities, Religion and Conflict"
}

Harold Coward

Follow this and additional works at: https://digitalcommons.butler.edu/jhcs

Part of the Religion Commons

\section{Recommended Citation}

Coward, Harold (1998) "Book Review: "The Colors of Violence: Cultural Identities, Religion and Conflict"," Journal of Hindu-Christian Studies: Vol. 11, Article 16.

Available at: https://doi.org/10.7825/2164-6279.1189

The Journal of Hindu-Christian Studies is a publication of the Society for Hindu-Christian Studies. The digital version is made available by Digital Commons @ Butler University. For questions about the Journal or the Society, please contact cbauman@butler.edu. For more information about Digital Commons @ Butler University, please contact digitalscholarship@butler.edu. 
First, she cites various infractions of the UNCRC in today's India due to discrimination in terms of caste, gender, and geographic origin. On the positive side she examines rituals, story telling, and role playing as important features for adults and children. Through these means "society tries to empower the potential child spiritually and seek for it a long life, strength and wisdom. Story telling and role playing enhance the child's knowledge of the tradition and shapes its world view". She concludes by observing that notwithstanding "patriarchal strains" the Hindu tradition does provide "the internal resources to combat the discrimination against children based on gender".

In his Conclusion, Harold Coward ignites a dilemma, flickering through the text - namely, how a specific religious view of the family can co-exist with the liberal democratic assumptions of the UN
Convention. For a solution to the dilemma, he draws on the political theories of Charles Taylor and finds in his arguments a corrective to the liberal presuppositions of the UNCRC. Readers will find Coward's own thesis much more convincing than the case study of a North American Aboriginal family he uses to examine the issues. In the final section, Coward shifts from critique to commendation with a summary of how the UNCRC principles in respect to girls and women are hailed by the religions as valid criticisms of their own traditional practices.

The chief asset of this volume is its capacity to serve as a resource for communities that must face the challenge of implementing the UNCRC through activities that harmonize with the beliefs and values of traditional religious cultures.

Cromwell Crawford

University of Hawaii

\section{The Colors of Violence: Cultural Identities, Religion and Conflict.} Sudhir Kakar. Chicago: University of Chicago Press, 1996, xiii $+217 \mathrm{pp}$.

THE STRENGTH OF this book is in its psychological analysis of the causes of communal riots in India. It is an extended case study of the Hindu-Muslim riots in Hyderabad in 1990, triggered by the Babri Masjid-Ramjanmabhoomi conflict. The book proceeds by way of interpretive interviews with both Hindu and Muslim leaders of violent mobs as well as with the victims of violence. Examples are also given of a Muslim family giving a Hindu family shelter and saving their lives during a riot. The author analyses friendships that cross communal divides. A convincing picture is presented of how communal violence can change forever the harmonious pattern of peaceful coexistence that crossed religious lines and typified many Indian communities in the past.

While focused on a Hindu-Muslim riot, the psychological dynamics uncovered apply as well to hostility between any religious communities. On an individual level it is the attitude expressed toward the Other who is sharing one's space in the community whether the Other is Muslim,. Sikh, or Christian, from a 'majority Hindu perspective, for example. The dynamic in India has been heightened since the time of partition. The psychological mechanism that Kakar most often uncovers is Freudian "projection". For example, seeing Muslims as "dirty" and as "sexual animals" is a projection by Hindus of their own instinctuality onto the Muslim. "other" or "out group". Kakar suggests that modernization 'prompts individuals increasingly to seek membership in groups with absolute value systems and with little tolerance for deviation from their norms - as 
a shelter for the hurt and disruption that industrialization brings (p.143). It is in these situations that new Muslim, Hindu, and other identities are created - identities much less tolerant of others and productive of the kinds of psychological projections that foster communal violence and intolerant religious fundamentalism. Kakar concludes, "what we are witnessing today is less the resurgence of religion than (in the felicitous Indian usage) of communalism where a community of believers not only has religious affiliation but also social, economic, and political corresponding interests of another community of believers sharing the same geographical space" (p.147). Many of the same dynamics are explored in literary form in Rohinton Mistry's excellent novel, $A$ Fine Balance.

With population increase and expanding modernization, communal forces encourage psychological projections onto the "other" that foster the kind of violence we see in India, Ireland, or Bosnia. Religious identity can expand one's sense of selfhood so as to create feelings of resonance with other believers, or foster communalism, intolerance, and the potential for social violence when the community believes itself to be threatened. Kakar's book makes a good beginning at uncovering the psychological dynamics at work.

Harold Coward University of Victoria

\section{The World's Parliament of Religions: The East-West Encounter,} Chicago, 1893. Richard H. Seager. Bloomington: Indiana University Press, 1995.

\section{READING THE PAINSTAKINGLY} researched and engrossingly written book on the 1893 World Parliament of Religions in Chicago makes one realize how the recent Centennial Parliament pales by comparison. Seager's careful scholarship convincingly shows that the original parliament marked a point of religious and cultural change in North America. In line with the liberal and evolutionary thinking of the 19th century, the Chicago Parliament set out to unite all religions against irreligion on the ground of Christianity as the superior tradition.

Seager's detailed analysis by text and photograph explores this fascinating event in all its complexity and shows it to be truly a watershed event in the creation of a more pluralistic religious culture in America. With his sustained focus on the East-West encounter, Seager shows how the utopian Judeo-Christian idealism that dominated thinking at the turn of the century was effectively challenged by a small group of Asians. Swami Vivekananda, the BramhoSamaji Majumdar, and the Buddhists Dharmapala of Ceylon, and Shabu Soen of Japan, challenged the naive assumption that the religions of the world could unite in "The Fatherhood of God" and the "Brotherhood of Man". These strangely dressed Eastern leaders demonstrated the real differences in their beliefs that caused the Parliament's attempt to realize the unity of all religions to fail. Both in their presentations at the Parliament and in their lecture tours after the Parliament these Asians exposed the ignorance and imperialism practised by many of the Christian missionaries to Asia, while at the same time demonstrating their own urbane and civilized qualities.

I especially like the author's skilful and 